\title{
Breaking dormancy, alternative substrates, and the production of Samanea tubulosa (Benth.) seedlings
}

Quebra de dormência, substratos alternativos e a produção de mudas de Samanea tubulosa (Benth.)

\author{
R. M. Costa ${ }^{1 *}$; M. R. Lima Leite ${ }^{1}$; S. dos S. Matos ${ }^{1}$; L. M. de P. Barbosa ${ }^{1}$; R. R. S. \\ da Silva-Matos'2 N. A. F. Machado ${ }^{3}$ \\ ${ }^{1}$ Federal University of Piauí (UFPI), 64049-550, Teresina-PI, Brazil \\ ${ }^{2}$ Department of Agronomy, Federal University of Maranhão (UFMA), 65500-000, Chapadinha-MA, Brazil \\ ${ }^{3}$ Federal University of Ceará (UFC), 60455-760, Fortaleza-CE, Brazil \\ *romario.martins90@hotmail.com \\ (Recebido em 19 de julho de 2020; aceito em 30 de março de 2021)
}

\begin{abstract}
We investigated different dormancy breaking methods and substrates for Samanea tubulosa seedlings. Four substrate formulations were tested: SCO: commercial substrate; BBA: decomposed babassu biomass + soil (1:1); BBU: buriti biomass + soil (1:1); and BCA: carnauba bagana + soil (1:1), and three dormancy breaking methods: EM: mechanical scarification; IA: immersion in water; and EQ: chemical scarification. The highest seedling emergence was in BCA substrate with chemical scarification. BCA and SCO provided the highest average seedling height, root length, root volume, root density, diameter at neck height, number of leaves, aboveground dry mass, belowground dry mass, and Dickson quality index values. Therefore, BCA can be used as a substrate for the production of S. tubulosa seedlings, and the immersion in water method is optimal when combined with a BBU substrate.
\end{abstract}

Keywords: Agroecology, organic waste, sustainability.

Investigamos diferentes métodos de quebra de dormência e substratos para mudas de Samanea tubulosa. Quatro formulações de substratos foram testadas: SCO: substrato comercial; BBA: biomassa decomposta de babaçu + solo (1:1); BBU: biomassa de buriti + solo (1:1); e BCA: bagana de carnaúba + solo (1:1), e três métodos de quebra de dormência: EM: escarificação mecânica; IA: imersão em água; e EQ: escarificação química. A maior emergência de plântulas ocorreu com um substrato de BCA com escarificação química. $\mathrm{O}$ substrato de BCA e SCO proporcionaram os maiores valores médios de altura, comprimento e volume radiculares, diâmetro radicular, diâmetro na altura do colo, número de folhas, massa seca da parte aérea, massa seca radicular e índice de qualidade de Dickson. Portanto, BCA pode ser usado como substrato para a produção de mudas de $S$. tubulosa, e o método de imersão em água é ideal quando combinado com um substrato de BBU.

Palavras chave: Agroecologia, resíduos orgânicos, sustentabilidade.

\section{INTRODUCTION}

Unsustainable agricultural practices for land use and management conducted by farmers in the humid tropics, such as along the periphery of the Amazon in the Brazilian state of Maranhão, are factors related [1] that increase soil degradation [2]. In addition, the practice of itinerant cutting and burning has accelerated deforestation in the Amazon [3, 4].

The use of native species is an important alternative in the recovery of degraded areas, as it allows the protection and enrichment of the soil, the control of erosion, less loss of water through evaporation and greater biological activity [5]. Among these species, Samanea tubulosa (Benth.) Barneby \& JW Grimes has been used in the restoration and maintenance of ecosystems in degraded areas $[6,7]$, being characterized as a typical tree in the Cerrado biome, reaching up to $28 \mathrm{~m}$ in height and $1 \mathrm{~m}$ in diameter, widely used in forestry, ornamentation and as part of animal nutrition $[8,9]$.

According to Dutra et al. (2013) [10], mechanical scarification, chemical scarification (usually with sulfuric acid), and hot water immersion are the notable methods for breaking the dormancy of seeds of forest species. These methods aim to dissolve the waxy cuticular layer, reducing the hardness of the integument and allowing an accelerated and uniform seed germination process. 
Seed dormancy is one of the main obstacles in the production of $S$. tubulosa seedlings, and results in seed loss, longer production times, and seedling unevenness [11]. Dormancy consists of delaying seed germination, which guarantees, from an ecological point of view, the distribution in time and space, however, for seedling production the attribute is not desirable, as there may be a low percentage of germination [12].

The use of commercial substrates that are based on expanded vermiculite and organic materials [13] is costly [7, 14], however, decomposed organic residues and fractions from Brazilian preAmazonian palms, such as babassu (Attalea speciosa Mart.), buriti (Mauritia vinifera Mart.), and carnauba (Copernicia prunifera Mill.), can reduce production costs without compromising seedling quality $[14,15,16,17,18]$. The aim of this study was to investigate three dormancy breaking methods (namely, mechanical scarification, immersion in water, and chemical scarification) and different substrates for $S$. tubulosa seedling production.

\section{MATERIAL AND METHODS}

\section{Location and climate}

The experiment was conducted from April to June 2018 at the Center for Agricultural and Environmental Sciences (CCAA) of the Federal University of Maranhão (UFMA), Chapadinha, Maranhão, Brazil ( $3^{\circ} 44^{\prime} 12.62^{\prime \prime} \mathrm{S}, 43^{\circ} 19^{\prime} 03.51^{\prime \prime} \mathrm{E}$, and $105 \mathrm{~m}$ above sea level). The region's climate is classified as humid tropical, with an average annual rainfall of $1613.2 \mathrm{~mm}$ and an average annual temperature of $26.9^{\circ} \mathrm{C}$ [19].

\section{Experimental design, treatments, and characterization procedures}

The study was conducted with a completely randomized design in a $4 \times 3$ factorial arrangement (four substrates and three dormancy breaking methods) with five replicates containing five plants each, totaling 25 plants per treatment and 300 plants in total, corresponding to 60 experimental units. Four substrate formulations were tested: SCO: commercial substrate; BBA: decomposed babassu biomass + soil (1:1); BBU: buriti biomass + soil (1:1); and BCA: carnauba bagana + soil (1:1), and three dormancy breaking methods: EM: mechanical scarification; IA: immersion in water; and EQ: chemical scarification.

SCO was composed of pine bark and vermiculite (Plantmax $\mathrm{HT}^{\circledR}$ ) and was used as a control, and soil used in the formulation of BBA, BBU, and BCA was collected from the $0-20 \mathrm{~cm}$ soil layer in the UFMA/CCAA experimental area. The soil was classified as a dystrophic Yellow Latosol [20], contained 560, 190, and $250 \mathrm{~g} \mathrm{~kg}^{-1}$ of sand, silt, and clay, respectively, had an "average" textural classification, and a degree of flocculation of $77 \mathrm{~g}^{100 \mathrm{~g}^{-1}}$.

The soil and substrate samples were sent to the Soil Science Laboratory of the Federal University of Ceará, Fortaleza, to measure global density, particle density, and total porosity (Table 1) according to the procedures described by Schmitz et al. (2002) [21], as well as pH, organic matter content, nitrogen, phosphorus, potassium, calcium, magnesium, and sulfur (Table 2) by the methodology described by MAPA (2007) [22]. 
Table 1. Physical characterization of the substrates.

\begin{tabular}{cccc}
\hline \multirow{2}{*}{ Substrates } & \multicolumn{2}{c}{ Density $\left(\mathbf{g ~ c m}^{-\mathbf{3}}\right)$} & \multirow{2}{*}{ Porosity $(\boldsymbol{\%})$} \\
\cline { 2 - 3 } & Global & Particle & \\
\hline SCO & 0.56 & 0.85 & 34.43 \\
BBA & 1.08 & 2.41 & 55.12 \\
BBU & 1.21 & 2.27 & 63.41 \\
BCA & 0.89 & 2.20 & 60.02 \\
\hline Solo & 1.44 & 2.67 & 45.99 \\
\hline
\end{tabular}

SCO: commercial substrate; BBA: babassu biomass + soil (1:1); BBU: buriti biomass + soil (1:1); and BCA: carnauba bagana + soil $(1: 1)$.

Table 2. Chemical characterization of the substrates.

\begin{tabular}{cllllllll}
\hline \multirow{2}{*}{ Substrates } & \multirow{2}{*}{$\mathbf{p H}$} & $\mathbf{M . O}$. & $\mathbf{N}$ & $\mathbf{P}$ & $\mathbf{K}$ & $\mathbf{C a}$ & $\mathbf{M g}$ & $\mathbf{S}$ \\
\cline { 3 - 8 } & & $\mathbf{g ~ k g}^{-1}$ & $\mathbf{g ~ k g}^{-1}$ & $\mathbf{~ m g ~ k g}^{-1}$ & & \multicolumn{2}{c}{$\mathbf{c m o l}_{\mathbf{c}} \mathbf{~ g}^{-1}$} & \\
\hline SCO & 4.9 & -- & 3.08 & 55.3 & 2.89 & 22.50 & 3.40 & 29.40 \\
BBA & 5.0 & 1.58 & 1.74 & 13.0 & 2.09 & 3.8 & 2.25 & 9.20 \\
BBU & 6.0 & 1.52 & 7.53 & 19.5 & 1.10 & 5.8 & 2.30 & 10.00 \\
BCA & 5.0 & 84.52 & 6.13 & 17.5 & 1.00 & 5.2 & 1.35 & 7.90 \\
\hline Solo & 5.06 & 15.41 & 0.63 & 3.01 & 0.07 & 0.88 & 0.30 & 1.50 \\
\hline
\end{tabular}

SCO: commercial substrate; BBA: babassu biomass + soil (1:1); BBU: buriti biomass + soil (1:1); and BCA: carnauba bagana + soil $(1: 1)$.

The S. tubulosa seeds were purchased from local stores. EM was performed using No. 180 sandpaper until the shiny surface of the seed coat was removed, IA was conducted in distilled water at room temperature for $24 \mathrm{~h}$, and EQ was performed using concentrated sulfuric acid $\left(\mathrm{H}_{2} \mathrm{SO}_{4}\right)$ for $5 \mathrm{~min}$, followed by washing for $5 \mathrm{~min}$ in running water.

\section{Experimental procedure}

Seeds were distributed in polyethylene bags $(12 \times 20 \mathrm{~cm})$ with two seeds per bag, in which they were buried at a depth of $1 \mathrm{~cm}$ for a period of 60 days. The bags were placed on a wooden bench in a greenhouse under controlled conditions. Daily watering was carried out to ensure adequate moisture within the substrate.

The count of emerged seeds was performed until 30 days after sowing (DAS), considering the seeds that contained the cotyledons fully open above the substrate. Subsequently, thinning was done, leaving only one plant per bag. The emergency percentage $(\% \mathrm{E})$ was calculated based on these data. At 60 DAS were measured: seedling height (SH, measured from the neck to the insertion of the last leaf), root length (RL), diameter at neck height (DNH), number of leaves (NL), root density (RD), aboveground dry mass (ADM), belowground dry mass (BDM), and total dry mass (TDM).

For the height and length measurements, rulers graduated in mm were used, for the diameter, a digital caliper was used, and to determine ADM and BDM, fresh material was placed in a forcedair-circulation oven for $72 \mathrm{~h}$ and then weighed on a precision scale. The Dickson quality index (DQI) was determined according to Equation 1 [23].

$$
\mathrm{DQI}=\mathrm{TDM} /(\mathrm{HP} / \mathrm{DSD}+\mathrm{SDM} / \mathrm{DMRS})
$$

Where: $\mathrm{TDM}=$ total dry mass $(\mathrm{g}) ; \mathrm{HP}=$ plant height $(\mathrm{cm}) ; \mathrm{DSD}=$ stem diameter $(\mathrm{cm}) ; \mathrm{SDM}=$ shoot dry matter $(\mathrm{g})$ : DMRS $=$ dry mass of the root system $(\mathrm{g})$. 


\section{Statistical analysis}

The data were subjected to an analysis of variance (Equation 2) followed by a Tukey test. Associations among the variables were assessed using Pearson's linear correlation coefficient (r) (Equation 3) and classified according to Gavioli et al. (2019) [24], where $0<\mathrm{r} \leq 0.2$ : no correlation; $0.2<\mathrm{r} \leq 0.4$ : weak correlation; $0.4<\mathrm{r} \leq 0.6$ : moderate correlation; $0.6<\mathrm{r} \leq 0.8$ : strong correlation; and $0.8<\mathrm{r} \leq 1$ : very strong correlation. $\mathrm{P}<0.05$ was set as statistical significance. Analyses were performed using Infostat 2018d statistical software [25], and figures were plotted using SigmaPlot 14.0.

$$
\text { Yeij }=\mu+\mathrm{Mi}+\mathrm{Sj}+\mathrm{Mi} \times \mathrm{Sj}+\text { Erroij }
$$

Where Yeij is the response variable, " $\mu$ " is the overall average, Mi is the $\mathrm{i}$-th method of breaking dormancy, $\mathrm{Sj}$ is the $\mathrm{i}$-th substrate, $\mathrm{Mi} \times \mathrm{Sj}$ is the interaction between the Mi-th dormancy breaking method and the $\mathrm{Sj}$-th substrate, and Erroij is the random error.

$$
r=\frac{1}{n-1} \sum_{i=1}^{n}\left(\frac{x i-\bar{x}}{S x}\right) \cdot\left(\frac{y i-\bar{y}}{S y}\right)
$$

Where $\mathrm{x}$ and $\mathrm{y}$ are the sample means of $\mathrm{x}$ and $\mathrm{y}$, respectively, and $\mathrm{Sx}$ and Sy are the sample standard deviations of $\mathrm{x}$ and $\mathrm{y}$, respectively.

\section{RESULTS}

There was a significant interaction effect between substrate type and dormancy breaking method on seedling emergence (Table 3). Using SCO, EM resulted in the highest seedling emergence (70.07\%). BCA and BBA provided the highest seedling emergence using $\mathrm{EQ}$, with respective values of 78.08 and $56.05 \%$. Using BBU, the best method for breaking dormancy was IA, with $50.05 \%$ seedling emergence.

Table 3. Emergence of Samanea tubulosa seedlings using different substrates and dormancy breaking methods.

\begin{tabular}{ccccccccc}
\hline \multirow{2}{*}{ Variable } & Substrate & \multicolumn{3}{c}{ Method } & \multirow{2}{*}{ CV $(\%)$} & \multicolumn{3}{c}{ P value } \\
\cline { 3 - 5 } & & EM & IA & EQ & & Substrate & Method & S x M \\
\hline \multirow{4}{*}{ EP $(\%)$} & SCO & $70.07 \mathrm{Aa}$ & $55.08 \mathrm{Ba}$ & $40.01 \mathrm{Cc}$ & & & & \\
& BBA & $24.06 \mathrm{Bb}$ & $20.01 \mathrm{Bb}$ & $56.05 \mathrm{Ab}$ & \multirow{2}{*}{10.51} & $<0.0001$ & $<0.0001$ & $<0.0001$ \\
& BBU & $30.01 \mathrm{Bb}$ & $50.05 \mathrm{Aa}$ & $30.05 \mathrm{Bd}$ & & & & \\
& BCA & $32.05 \mathrm{Bb}$ & $20.04 \mathrm{Cb}$ & $78.08 \mathrm{Aa}$ & & & & \\
\hline
\end{tabular}

Averages followed by uppercase letters in the row and lowercase letters in the column did not significantly differ according to a Tukey test at $5 \%$ significance. $\mathrm{CV}$, coefficient of variation; $\mathrm{S} \times \mathrm{M}$, substrate $\times$ dormancy breaking method; EM, mechanical scarification; IA, immersion in water; EQ, chemical scarification; SCO, commercial substrate; BBA, babassu biomass; BBU, buriti biomass; BCA, carnauba bagana; EP, seedling emergence.

There was no significant interaction effect between dormancy breaking method and substrate (P $>0.05$ ) on $\mathrm{SH}, \mathrm{RL}$, root volume (RV), or RD, suggesting that these factors acted independently (Table 4). 
Table 4. Effect of substrate $(S)$, dormancy breaking method $(M)$, and substrate $\times$ dormancy breaking method $(S \times M)$ on seedling height, root length, root volume, and root density.

\begin{tabular}{ccccc}
\hline \multirow{2}{*}{ Variable } & \multirow{2}{*}{ CV $(\boldsymbol{\%})$} & \multicolumn{3}{c}{ P value } \\
\cline { 3 - 5 } & & Substrate & Method & S x M \\
\hline Seedling height & 9.79 & $<0.0001$ & 0.0027 & 0.1097 \\
Root length & 14.24 & $<0.0001$ & 0.1686 & 0.1659 \\
Root volume & 30.05 & $<0.0001$ & 0.2655 & 0.1330 \\
Root density & 27.44 & $<0.0001$ & 0.6210 & 0.7223 \\
\hline
\end{tabular}

Substrates based on BCA and SCO had the highest average $\mathrm{SH}$, with values of 15.30 and 14.44 $\mathrm{cm}$, respectively, which did not significantly differ $(\mathrm{P}>0.05)$ (Figure 1A). Seedling RLs in BCA and BBU were similar to those in the control (SCO) (Figure 1B), and SCO $(2.63 \mathrm{~mL}$ ) and BCA $(2.11 \mathrm{~mL})$ had the highest average RVs, which did not significantly differ (Figure 1C). BCA (0.17 $\left.\mathrm{g} \mathrm{mL}^{-1}\right), \mathrm{SCO}\left(0.15 \mathrm{~g} \mathrm{~mL}^{-1}\right)$, and BBU $\left(0.15 \mathrm{~g} \mathrm{~mL}^{-1}\right)$ gave the best results for RD (Figure 1D) and did not significantly differ. The BBA-based substrate gave the lowest average SH, RL, RV, and $\mathrm{RD}$ values.
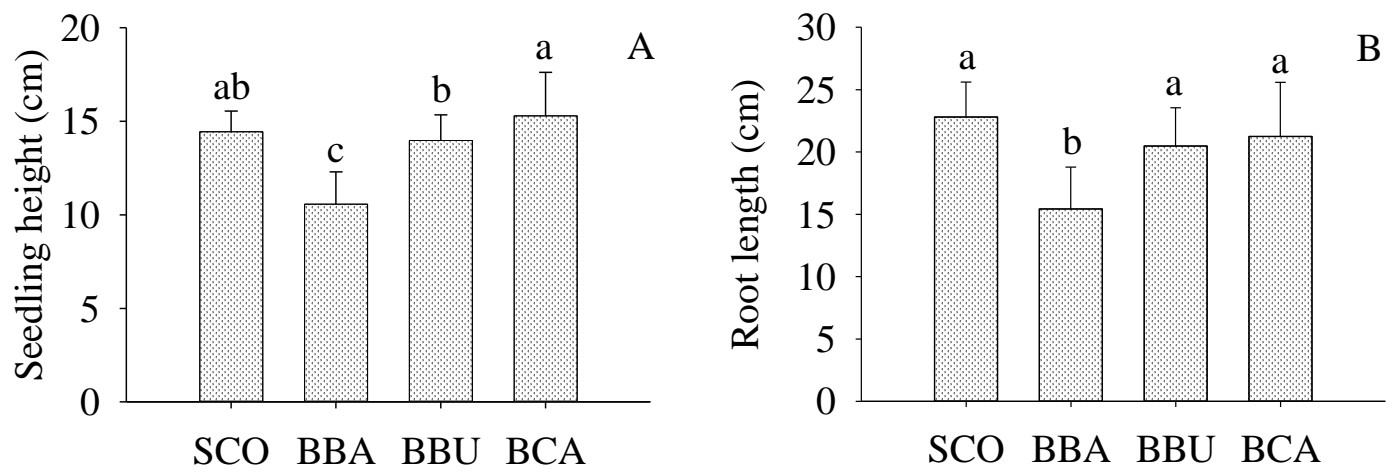

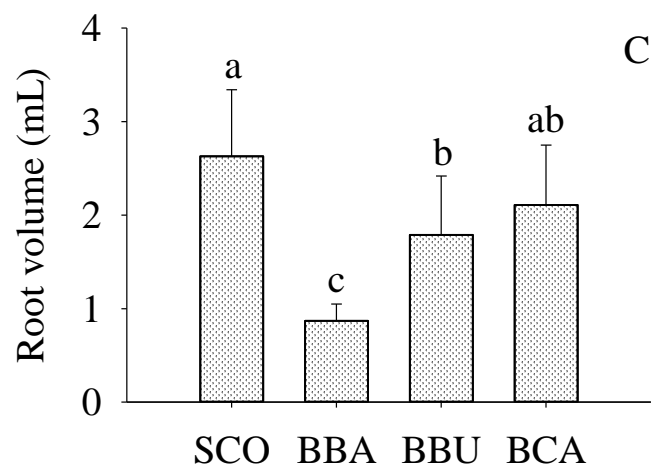

Substrates

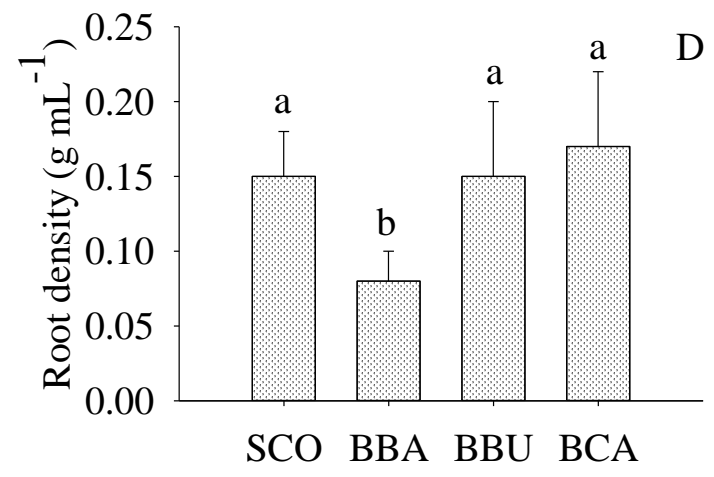

Substrates

Figure 1. Seedling height (A), root length $(B)$, root volume $(C)$, and root density $(D)$ of Samanea tubulosa seedlings in different substrates. Averages followed by equal letters did not significantly differ according to a Tukey test at 5\% significance. Bars indicate standard deviation.

There was a significant interaction effect between substrate type and dormancy breaking method on $\mathrm{DNH}, \mathrm{NL}, \mathrm{ADM}, \mathrm{BDM}$, and $\mathrm{DQI}$ (Table 5). SCO and BCA provided the highest average $\mathrm{DNH}$, regardless of the dormancy breaking method employed. There was no difference between methods using the BBA-based substrate, which had the lowest averages. The BBU substrate gave higher DNH using the EQ method than EM (Table 5). 
The use of SCO, BCA, and BBU resulted in the highest NL, with no differences between the dormancy breaking methods. Using BBA, EM provided a higher NL than AI (Table 5). There were no significant differences in ADM among the methods, regardless of the type of substrate used, except for BCA, which provided higher ADM using the AI method than EQ. BCA had the highest values, regardless of the dormancy breaking method employed.

The highest BDM values were found using SCO and BCA, which were not significantly different. Using BCA, the best methods were EM and IA, while using BBU, the best dormancy breaking method was EQ. SCO and BCA gave the highest DQI values and did not significantly differ, regardless of the method employed (Table 5). BBA and BBU had the lowest values, and only by using the EQ method was the BBU substrate as successful as SCO and BCA.

We found significant, positive correlations $(\mathrm{P}<0.05$ and $\mathrm{P}<0.01)$ among all of the variables under study (Table 6), in contrast to Gavioli et al. (2019) [24], who only reported weak correlations among them.

SH was very strongly correlated with ADM and TDM and strongly correlated with RL, RV, BDM, DQI, and RD. NL was only weakly correlated with the other variables (Table 6).

Table 5. Diameter at neck height, number of leaves, aboveground dry mass, belowground dry mass, and Dickson quality index values of seedlings using different substrates and dormancy breaking methods.

\begin{tabular}{|c|c|c|c|c|c|c|}
\hline \multirow{2}{*}{ Variable } & \multirow{2}{*}{ Substrate } & \multicolumn{3}{|c|}{ Method } & \multirow[t]{2}{*}{ CV (\%) } & \multirow{2}{*}{$\begin{array}{c}\text { P value } \\
S \times M \\
\end{array}$} \\
\hline & & EM & IA & EQ & & \\
\hline \multirow{4}{*}{ DNH (mm) } & $\mathrm{SCO}$ & 3.46Aa & $3.28 \mathrm{Aa}$ & $3.49 \mathrm{Aa}$ & \multirow{4}{*}{13.69} & \multirow{4}{*}{0.0306} \\
\hline & BBA & $1.93 \mathrm{Ab}$ & $1.85 \mathrm{Ab}$ & $2.34 \mathrm{Ab}$ & & \\
\hline & $\mathrm{BBU}$ & $1.99 \mathrm{Bb}$ & $2.37 \mathrm{ABb}$ & $2.85 \mathrm{Aab}$ & & \\
\hline & $\mathrm{BCA}$ & 3.17Aa & $3.22 \mathrm{Aa}$ & $2.92 \mathrm{Aab}$ & & \\
\hline \multirow{4}{*}{ NL } & $\mathrm{SCO}$ & $14.30 \mathrm{Aa}$ & $13.70 \mathrm{Aa}$ & $12.40 \mathrm{Aa}$ & \multirow{4}{*}{16.27} & \multirow{4}{*}{0.0048} \\
\hline & BBA & $10.73 \mathrm{Aa}$ & $6.00 \mathrm{Bb}$ & $6.66 \mathrm{ABb}$ & & \\
\hline & $\mathrm{BBU}$ & $13.90 \mathrm{Aa}$ & $16.92 \mathrm{Aa}$ & 15.20Aa & & \\
\hline & BCA & $12.80 \mathrm{Aa}$ & $14.31 \mathrm{Aa}$ & $12.33 \mathrm{Aa}$ & & \\
\hline \multirow{4}{*}{$\operatorname{ADM}(\mathrm{g})$} & $\mathrm{SCO}$ & $0.77 \mathrm{Ab}$ & $0.82 \mathrm{Ab}$ & $0.90 \mathrm{Aa}$ & \multirow{4}{*}{23.00} & \multirow{4}{*}{0.0003} \\
\hline & BBA & $0.21 \mathrm{Ac}$ & $0.16 \mathrm{Ac}$ & $0.19 \mathrm{Ab}$ & & \\
\hline & $\mathrm{BBU}$ & $0.54 \mathrm{Abc}$ & $0.64 \mathrm{Ab}$ & 0.89Aa & & \\
\hline & BCA & 1.17ABa & $1.43 \mathrm{Aa}$ & $0.93 \mathrm{Ba}$ & & \\
\hline \multirow{4}{*}{ BDM (g) } & $\mathrm{SCO}$ & $0.34 \mathrm{Aa}$ & 0.37Aab & $0.46 \mathrm{Aa}$ & \multirow{4}{*}{30.07} & \multirow{4}{*}{0.0001} \\
\hline & BBA & $0.06 \mathrm{Ab}$ & $0.06 \mathrm{Ac}$ & $0.07 \mathrm{Ab}$ & & \\
\hline & $\mathrm{BBU}$ & $0.21 \mathrm{Bab}$ & $0.20 \mathrm{Bbc}$ & $0.40 \mathrm{Aa}$ & & \\
\hline & $\mathrm{BCA}$ & $0.38 \mathrm{ABa}$ & $0.49 \mathrm{Aa}$ & $0.28 \mathrm{Ba}$ & & \\
\hline \multirow{4}{*}{ DQI } & $\mathrm{SCO}$ & $0.17 \mathrm{Aa}$ & $0.18 \mathrm{Aa}$ & $0.20 \mathrm{Aa}$ & \multirow{4}{*}{29.75} & \multirow{4}{*}{0.0010} \\
\hline & BBA & $0.03 \mathrm{Ab}$ & $0.03 \mathrm{Ab}$ & $0.03 \mathrm{Ab}$ & & \\
\hline & $\mathrm{BBU}$ & $0.08 \mathrm{Bb}$ & $0.09 \mathrm{ABb}$ & $0.17 \mathrm{Aa}$ & & \\
\hline & BCA & $0.21 \mathrm{Aa}$ & $0.21 \mathrm{Aa}$ & $0.14 \mathrm{Aa}$ & & \\
\hline
\end{tabular}

Averages followed by uppercase letters in the row and lowercase letters in the column did not significantly differ according to a Tukey test at 5\% significance. $\mathrm{CV}$, coefficient of variation; $\mathrm{S} \times \mathrm{M}$, substrate $\times$ dormancy breaking method; EM, mechanical scarification; IA, immersion in water; EQ, chemical scarification; SCO, commercial substrate; BBA, babassu biomass; BBU, buriti biomass; BCA, carnauba bagana; DNH, diameter at neck height; NL, number of leaves; ADM, aboveground dry mass; BDM, belowground dry mass; DQI, Dickson quality index. 
Table 6. Pearson correlation matrix of growth and quality variables in Samanea tubulosa seedlings in different substrates.

\begin{tabular}{lccccccccc}
\hline & SH & RL & DNH & NL & RV & ADM & BDM & TDM & DQI \\
\hline RL & $0.63^{* *}$ & & & & & & & & \\
DNH & $0.56^{* *}$ & $0.47^{* *}$ & & & & & & Very strong & \\
NL & $0.38^{* *}$ & $0.33^{* *}$ & $0.29^{*}$ & & & & & Strong & \\
RV & $0.69^{* *}$ & $0.66^{* *}$ & $0.65^{* *}$ & $0.33^{* *}$ & & & & Moderate & \\
ADM & $0.81^{* *}$ & $0.59^{* *}$ & $0.63^{* *}$ & $0.33^{* *}$ & $0.77^{* *}$ & & & Weak & \\
BDM & $0.77^{* *}$ & $0.65^{* *}$ & $0.65^{* *}$ & $0.33^{* *}$ & $0.89^{* *}$ & $0.91^{* *}$ & & No & \\
TDM & $0.81^{* *}$ & $0.62^{* *}$ & $0.65^{* *}$ & $0.35^{* *}$ & $0.82^{* *}$ & $0.99^{* *}$ & $0.96^{* *}$ & & \\
DQI & $0.72^{* *}$ & $0.62^{* *}$ & $0.76^{* *}$ & $0.30^{*}$ & $0.87^{* *}$ & $0.93^{* *}$ & $0.97^{* *}$ & $0.96^{* *}$ & \\
RD & $0.67^{* *}$ & $0.50^{* *}$ & $0.37^{* *}$ & $0.37^{* *}$ & $0.48^{* *}$ & $0.80^{* *}$ & $0.78^{* *}$ & $0.81^{* *}$ & $0.73^{* *}$ \\
\hline
\end{tabular}

* and **: significant at 5\% and 1\%, respectively. SH, seedling height; RL, root length; DNH, diameter at neck height; NL, number of leaves; RV, root volume; ADM, aboveground dry mass; BDM, belowground dry mass; TDM, total dry mass; DQI, Dickson quality index; RD, root density.

\section{DISCUSSION}

Choosing what type of substrate to use is associated with the inherent physical and chemical characteristics of each substrate, such as porosity and density that influence water absorption and retention, as well as the availability of nutrients necessary for good seedling development Dorneller et al. (2014) [26]. In the present study, the type of substrate used for the production of S. tubulosa seedlings influenced the efficiency of the method for breaking seed dormancy.

EM is a simple, low-cost technique that cracks seeds in order to reduce the impermeability of the seed coat. However, the technique can damage the embryo, and affect germination and seedling emergence [27, 28]. In the present study, this method was particularly efficient in SCO by exposing the embryo and facilitating the imbibition process. Although this substrate had the lowest porosity (Table 1), suggesting lower infiltration, the amount of water was sufficient to achieve $70 \%$ seedling emergence.

Sulfuric acid accelerates the imbibition process by breaking the seed coat, which results in greater seedling emergence [29]. Using EQ, seedling emergence in BCA and BBA may have been related to their physical characteristics, because their total porosity was 14.03 and $9.13 \%$ higher, respectively, than soil with no organic residue (Table 1). In addition, according to Pagliarini et al. (2012) [30], the increase in porosity is associated with an increase in aeration and water infiltration, providing adequate moisture for the emergence of seedlings.

Oliveira et al. (2012) [29] investigated pre-germinative treatments for S. tubulosa seeds using washed sand (high porosity) as a substrate, and found that the highest percentage $(>70 \%)$ of seedling emergence occurred with the use of concentrated sulfuric acid for 5 and $15 \mathrm{~min}$, which is similar to the results of the present study.

IE for $24 \mathrm{~h}$ was most effective in BBU, which had $>50 \%$ seedling emergence probably because of its highly porous nature $(63.41 \%)$. This provided greater infiltration, optimized seed soaking, and weakened the integument. In this respect, BBU stands out from the other substrates studied, because in addition to being found in abundance in the Amazon and pre-Amazon regions, AI can be used to break dormancy in seeds with hard integuments. This would bring great economic benefits to the seedling producer because the raw material is widely available and cheap, in contrast to the sulfuric acid used in EQ, which has restricted use and is expensive, in addition to harming the environment. The IA method increases the permeability of the seed tissue owing to wear or softening, thus facilitating the diffusion of water into the embryo [31].

Although BCA only had low levels of nitrogen in its composition (Table 2), it contained high levels of organic matter that may have provided a controlled release of nitrogen during seedling development and affected their size (Figure 1A). According to Guerrini and Trigueiro (2004) [32], organic matter is a fundamental component in the substrates. It is capable of increasing the water 
retention capacity, improving the physical characteristics of the substrate, and providing nutrients for the seedlings, in addition to being closely related to organic carbon.

BBA gave the lowest average RL (Figure 1B) probably because of its low levels of phosphorus (Table 2), which is closely linked to root growth. The highest averages for RV and RD (Figures 1C and 1D) were attributed to a large root mass, given the very strong and strong significant correlations, respectively, between these variables (Table 6). The high phosphorous levels in BCA, $\mathrm{SCO}$, and BBU probably increased RD.

SCO and BCA gave the best DNH results, probably because of its strong correlation with RV (Table 6), suggesting that increased root growth results in greater stem thickening.

$\mathrm{NL}$ is an important parameter that is used in choosing the best seedlings in terms of photosynthetic capacity [33]. The results obtained using SCO, BCA, and BBU can be attributed to the levels of nutrients present in each substrate, particularly nitrogen and potassium that are needed in cell division and directly affect seedling growth and development, which are reflected in the NL.

The NL and ADM results were related to the levels of nitrogen and phosphorus present in the BCA substrate (Table 2). According to Faria et al. (2016) [34], these are the most important nutrients during the initial phase of seedling growth, because they play important roles in enzymatic processes, cell maintenance and turgidity, energy storage, and cell growth and elongation. Organic matter is an important component of BCA because it improves the physical, chemical, and biological properties of the substrate.

The high BDM values of plants grown in SCO and BCA can be attributed to their phosphorus concentrations, given their effects on root development, as well as their physical characteristics such as density and porosity, because high porosity and low density provide greater water retention and favor root development [35].

SCO and BCA had macronutrient levels that were adequate for plant development, as reflected in their high DQI values (Table 5). DQI is a measure of seedling quality, and seedlings with a high DQI value have high phytomass, vigor, and, consequently, greater production capacity [36].

SH was very strongly correlated with ADM and TDM (Table 5), indicating that seedling size is positively related to ADM and TDM values. This may have been due to greater light and carbon dioxide capture, resulting in higher photosynthetic activity.

The very strong correlations found between DQI and ADM, BDM, and TDM were probably caused by the dependence of this index on TDM and the ADM/BDM ratio used in calculating its value. Therefore, $S$. tubulosa seedlings with high TDM values and good ADM/BDM ratios had high DQI values.

NL was weakly correlated with all of the growth variables (SH, RL, DNH, RV, ADM, BDM, and TDM) and seedling quality (DQI), indicating that NL alone cannot explain the responses of the other variables studied [33].

\section{CONCLUSIONS}

Carnauba bagana may be used as an alternative substrate to the commercial substrate for the production of $S$. tubulosa (Benth.) seedlings; when combined with the chemical scarification method using sulfuric acid, it accelerated the emergence of seedlings. When buriti biomass was used as the substrate, the method of immersion in water for $24 \mathrm{~h}$ was satisfactory for overcoming the tegumentary dormancy of $S$. tubulosa seeds. The use of babassu biomass as the substrate was not suitable for the production of $S$. tubulosa seedlings.

\section{ACKNOWLEDGMENTS}

We would like to thank Editage (www.editage.com) for English language editing. 


\section{REFERENCES}

1. Lima GP, Peixoto Neto CAA, Amaral YT, Siqueira GM. Biogeographical characterization of the maranhense Eastern Mesoregion (Brazil). Journal of Geospatial Modelling. 2016;1(1):1-12, doi: 10.22615/jgm-1.1-5809

2. Moura-Silva AG, Aguiar ACF, Jorge N, Agostini-Costa TS, Moura EG. Food quantity and quality of cassava affected by leguminous residues and inorganic nitrogen application in a soil of low natural fertility of the humid tropics. Bragantia. 2017;76(3):406-15, doi: 10.1590/1678-4499.007

3. Aguiar ACF, Freitas IC, Carvalho CS, Monroe PHM, Moura EG. Efficiency of an agrosystem designed for family farming in pre-Amazon region. Renew Agric Food Syst. 2011;26(1):24-30, doi: 10.1017/S1742170510000396

4. Moura EG, Portela SB, Macedo VRA, Sena VGL, Sousa CCM, Aguiar ACF. Gypsum and legume residue as a strategy to improve soil conditions in sustainability of agrosystems of the humid tropics. Sustainability. 2018;10(1006):1-12, doi: 10.3390/su10041006

5. Sansevero JBB, Prieto PV, Moraes LFD, Rodrigues PJFP. Natural regeneration in plantations of native trees in lowland Brazilian Atlantic Forest: community structure, diversity, and dispersal syndromes. Restoration Ecology, 2011;19(3):379-89, doi: 10.1111/j.1526-100X.2009.00556.x

6. Marcuzzo SB, Araújo MM, Gasparin E. Plantio de espécies nativas para restauração de áreas em unidades de conservação: um estudo de caso no sul do Brasil. Floresta. 2015;45(1):129-40, doi: 10.5380/rf.v45i1.32763

7. Silva EP, Figueiredo FG, Séfara S, Fernandes L. Evaluation of the potential of seed rain as an alternative for forest restoration in Permanent Preservation Areas. Rev Árvore. 2016;40(1):21-8, doi: 10.1590/010067622016000100003

8. Carvalho PER. Bordão-de-velho (Samanea tubulosa). Colombo (PR): Embrapa Florestas; 2007. (Circular Técnica, 132). Available from: https://ainfo.cnptia.embrapa.br/digital/bitstream/CNPF-200909/42344/1/Circular132.pdf

9. Lorenzi H. Árvores brasileiras: manual de identificação e cultivo de plantas arbóreas nativas do Brasil. Nova Odessa (SP): Instituto Plantarum; 2002. 201 p.

10. Dutra TR, Massad MD, Sarmento MFQ, Oliveira JC. Substratos alternativos e métodos de quebra de dormência para produção de mudas de canafístula. Rev Ceres. 2013;60(1):72-8, doi: 10.1590/S0034737X2013000100011

11. Poletto T, Muniz MFB, Poletto I, Baggiotto C. Métodos de superação de dormência da semente de nogueira-pecã Carya illinoinensis (Wangenh.) K. Koch. Rev Árvore. 2015;39(6):1111-18, doi: 10.1590/0100-67622015000600014

12. Abreu DCA, Porto KG, Nogueira AC. Métodos de superação da dormência e substratos para germinação de sementes de Tachigali vulgaris L. G. Silva \& H. C. Lima. Floram. 2017;24(e00071814):2-10, doi: 10.1590/2179-8087.071814

13. Cavalcante IHL, Petter FA, Albano FG, Silva-Matos RRS, Silva Júnior GB. Biochar no substrato para produção de mudas de maracujazeiro amarelo. Rev Fac Agron Univ Nac La Plata. 2012;111(1):41-7.

14. Cordeiro KV, Andrade HAF, Oliveira-Neto ED, Costa NA, Rocha BR, Pontes SF, Marzullo YO, Pinto FEN, Machado NAF, Silva-Matos RRS. New substrates based on decomposed babassu (Attalea speciosa Mart.) stem in the production of melon seedlings. J Exp Agric Int. 2018;2(1):1-7, doi: 10.9734/JEAI/2018/43888

15. Albano FG, Cavalcante IHL, Machado JS, Lacerda CF, Silva ER, Sousa HG. New substrate containing agroindustrial carnauba residue for production of papaya under foliar fertilization. Rev Bras Eng Agríc Ambient. 2017;21(2):128-33, doi: 10.1590/1807-1929/agriambi.v21n2p128-133

16. Andrade HAF, Costa NA, Cordeiro KV, Oliveira Neto ED, Albano FG, Silva-Matos RRS. Caule decomposto de babaçu (Attlea speciosa Mart.) como substrato para produção de mudas de melancieira. Cult Agron. 2017;26(3):406-16.

17. Costa E, Binotti FFS, Cardoso ED, Lima Júnior DB, Zoz T, Zuffo AM. Cherry tomato production on different organic substrates under protected envorinment conditions. Aust J Crop Sci. 2018;12(1):87-92, doi: 10.21475/ajcs.18.12.01.pne749

18. Silva-Matos RRS, Silva GB, Marques AS, Monteiro ML, Cavalcante IHL, Osajima JA. New organic substrates and boron fertilizing for production of yellow passion fruit seedlings. Arch Agron Soil Sci. 2015;62(3)445-55, doi: 10.1080 / 03650340.2015.1050000

19. Passos MLV, Zambrzycki GC, Pereira RS. Balanço hídrico e classificação climática para uma determinada região de Chapadinha-MA. Rev Bras Agric Irrig. 2016;10(4):758-66, doi: 10.7127/rbai.v10n400402 
20. Santos HG, Jacomine PKT, Anjos LHC, Oliveira VA, Lumbreras JF, Coelho MR, Almeida JA, Cunha TJF, Oliveira JB. Sistema Brasileiro de Classificação de Solos. 3 ed. Brasília (DF): Embrapa; 2013. 353 p.

21. Schmitz JAK, Souza PVD, Kampf AN. Propriedades químicas e físicas de substratos de origem mineral e orgânica para cultivo de mudas em recipientes. Cienc Rural. 2002;32(6):937-44, doi: 10.1590/S010384782002000600005

22. Ministério da Agricultura, Pecuária e Abastecimento (MAPA), Secretaria de Defesa Agropecuária. Instrução Normativa SDA n ${ }^{\circ} 17$ de 21 de maio 2007. Diário Oficial da União. 24 mai 2017;99(Seção1):89.

23. Dickson A, Leaf AL, Hosner JF. Quality appraisal of white spruce and white pine seedling stock in nurseries. Forest Chron. 1960;36(1):10-3, doi: 10.5558/tfc36010-1

24. Gavioli A, Souza EG, Bazzi CL, Schenatto K, Betzek NM. Identification of management zones in precision agriculture: An evaluation of alternative cluster analysis methods. Biosyst Eng. 2019;181:86102, doi: 10.1016/j.biosystemseng.2019.02.019

25. Di-Rienzo JA, Casanoves F, Balzarini MG, Gonzalez L, Tablada M, Robledo CW. InfoStat. Versión 2018. Argentina: Grupo InfoStat, FCA, Universidad Nacional de Córdoba; 2018.

26. Dornelles P, Silva FG, Mota CS, Santana JG. Production and quality of Anacardium othonianum Rizz. seedlings grown in different substrates. Rev Bras Frutic. 2014;36(2):479-86, doi: 10.1590/0100-2945$144 / 13$

27. Eira MTS, Freitas RWA, Mello CMC. Superação da dormência de sementes de Enterolobium contortisiliquum (Vell.) Morong. - Leguminosae. Rev. Bras Sementes. 1993;15(2):177-82.

28. McDonald M, Copeland LO. Seed production: principles and practices. New Jersey (US): Chapmam \& Hall, Springer; 1997. 749 p.

29. Oliveira AKM, Ribeiro JWF, Pereira KCL, Rondon EV, Becker TJA, Barbosa LA. Superação de dormência em sementes de Parkia gigantocarpa (Fabaceae - Mimosidae). Cienc Florest. 2012;22(3):53340, doi: 10.5902/198050986620

30. Pagliarini MK, Castilho RMM, Alves MC. Caracterização físico-química de misturas de componentes de substrato com resíduo de celulose para fins de produção de mudas. Rev Bras de Agroecologia. 2012;7(2):160-169.

31. Mertz LM, Henning FA, Cruz HL, Meneghello GE, Ferrari CS, Zimmer PD. Diferenças estruturais entre tegumentos de sementes de soja com permeabilidade contrastante. Ver Bras Sementes. 2009;31(1):23-29, doi: 10.1590/S0101-31222009000100003

32. Guerrini IA, Trigueiro RM. Atributos físicos e químicos de substratos compostos por biossólidos e casca de arroz carbonizada. Rev Bras Ciênc Solo. 2004;28(6):1069-1076, doi: 10.1590/S010006832004000600016

33. Gasparin E, Avila AL, Araujo MM, Cargnelutti Filho A, Dorneles DU, Foltz DRB. Influência do substrato e do volume de recipiente na qualidade das mudas de Cabralea canjerana (Vell.) Mart. em viveiro e no campo. Cienc Florest. 2014;24(3):553-63, doi: 10.5902/1980509815731

34. Faria JCT, Caldeira MVW, Derlamelina WM, Rocha RLF. Substratos alternativos na produção de mudas de Mimosa setosa Benth. Cienc Florest. 2016;26(4):1075-86, doi: 10.5902/1980509824996

35.Zorzeto TQ, Dechen SCC, Abreu MF, Fernandes FJ. Caracterização física de substratos para plantas. Bragantia. 2014;73(3):300-11, doi: 10.1590/1678-4499.0086

36. Souza RR, Matias SSR, Silva RR, Silva RL, Barbosa JSM. Qualidade de mudas de mamão produzidas em substrato com esterco caprino e doses de superfosfatos simples. Agrarian. 2015;8(28):139-46. 